\title{
Occupational stress among the New Zealand farmers \\ - A review
}

\author{
Huat Bin (Andy), Ang \\ Auckland University of Technology
}

\begin{abstract}
A review of the literature notes that farmers are experiencing high level of stress due to the impact of various uncontrollable factors in the work environment. Occupational stress pertinent to the New Zealand agriculture sector includes: (i) economic factors, (ii) adjusting to government regulations, (iii) labour shortage, (iv) effect of trade globalisation, (v) climatic conditions, and (vi) size of the farm. The empirical data from the existing published journal are compared with results from the current study. This study contributes to the literature by examining the extent of occupational stress in the New Zealand primary sector compare with their European counterpart.
\end{abstract}

\section{Introduction}

Farming is a complex way of living that creates stressful life conditions among farmers in the primary sector. Occupational stress contributes not only to life stresses, but has an impact on health and, thus, on the quality of farm life experienced by farmers (Pollock et al., 2002; Walker \& Walker, 1987). According to Burrow (2002), the negative impact of occupational stress on health and well-being is on the increase. As such, identifying workers involved at high risk of occupational stressors and strains has been the focus of attention amongmuch attention is that it is causing billions of dollars of losses per annum to the New Zealand economy (Grant \& Langan-Fox, 2007; Kinman, 2001).

Occupational stress is not the specific problem of one sector but pervades the whole agricultural industry, although some groups are better able to handle stressful situations (Lobley, Johnson, Reed, with Winter, \& Little, 2004). National Institute for Occupational Safety and Health (2002) has reported that farmers are in the top category of stress-related illness by occupational group.

However, the restructuring of agricultural economies globally, which began in the mid-1980s, imposed severe adjustment pressures on all farm sectors in various countries. Since 1984, the New Zealand agricultural sector has not been subsidized at all which has led to increased stress among farmers and many bankruptcies (Wilson, 1995). As with the North American farmers, they are experiencing one of the highest levels of occupational stress as a result of the current world economic crisis and the uncertainties in the markets (Lobley et al., 2004)..Meanwhile, European farmers are also encountering a period of significant socio-economic transition, largely as a result of the mechanization of farming practices and the demands brought about by the Common Agricultural Policy (CAP) (Booth \& Lloyd, 2000). Taken together, the impact of agricultural policy reforms, as well as market uncertainties, have been linked to occupational stress (Smith \& Saunders, 1995).

\section{Occupational stress}

Occupational stress is a widespread problem that is costly and destructive at the individual and organizational levels. New Zealand's agricultural sector has one of the highest rates of work-related injury and illness. Although agriculture is a vital industry employing 7\% of New Zealand's labour force, this sector has reported an average of 26 cases per year of fatalities which is amongst the highest recorded since 1997 (Department of Labour, 2007). The number of cases involving injuries and fatalities are related to the accident claims in the primary sector. Due to the high risk of working on the farm, eleven farmers injure themselves every day. At least one farmer is killed every two to three weeks (Accident Compensation Corporation, 2006; Department of Labour, 2004).

Research also shows that farming in New Zealand is inherently more dangerous than other occupations as it entails coming in contact with heavy machinery and livestock as well as often working alone, frequently in isolated, rugged terrain (Morgaine, Langley, \& McGee, 2006). The farmers become stressed with their traditional farm work due to financial pressure, poor time management, lack of self management, employment turnover, and the managing of inefficient workers (Tipples, 2005).

In respect of the high number of accidents on the farm industry, what are the physiological and psychological causes that are likely to contribute to risk in the workplace? As a hazardous occupation, farmers are 
exposed to variety of physical, chemical, biological and psychosocial factors (Firth, 2001). Overseas studies have shown that the psychological injuries and distress have been associated with increased rates of strain and job dissatisfaction (Burton et al., 2005; Cooper \& Bramwell, 1992). Moreover, this issue is not confined to New Zealand farmers and there is emergent international interest on the impact of stress on farmers and the wider implications for families and rural communities.

\section{Occupational Stress in Farming}

Since the early 1980 s, the study of occupational stress in farming began to receive attention from researchers (Eberhardt \& Pooyan, 1990; Schellenberg, Olson, \& Fuller, 1985). Research most notably involving farmers has focused primarily on associations between external environment and health outcomes such as depression, anxiety, and heart disease (Smith \& Saunders, 1995).

One of the reasons that occupational stress in the primary sector has been receiving so much attention is that it is costing losses in billions of dollars to the New Zealand economy. A study by Coggan, Fanslow, and Norton (1995) estimate that New Zealanders lost an average gross wage of NZ\$30,000 per year from the loss of production due to injury. Every year, as much as 10 percent of the gross national product was reported lost in the western countries from various effects of job stress (Arnold, Cooper, \& Robertson, 1998). Further, International Labour Organization reports that the cost of stress related illness and injury may account for approximately $2 \%$ of Gross Domestic Product per year in the OECD countries (Hoel, Sparks, \& Cooper, 2001).

Occupational stress is not the specific problem of one sector but pervades the whole agricultural industry, although some groups are able to handle stressful situations (Lobley, et al., 2004). National Institute for Occupational Safety and Health has reported that one of the top lists of stress-related illness by occupational group is the farmers. Further, Sayetta and Johnson (1980) reported stress related symptoms are higher among farmers than other occupational groups. They differ significantly from the rest of the workforce in regard to occupational health and safety issues (Hope, Kelleher, \& Hennessy, 1999). Occupational stress pertinent to the New Zealand agriculture sector is addressed as follows:-

\section{a. Economic factors}

New Zealand farmers are involved in diverse types of farming in the agricultural activities, including dairying, horticultural, beef production, venison, forestry, feed grains and cropping. The economic circumstances in agriculture may well affect different groups of farmers at different times. Although these farming industry have different seasonal patterns, they are facing similar problems and circumstances throughout the country, such as industry restructuring and economic trends from the post-war era and the deregulation of employment relations (Shadbolt \& Martin, 2005). Since 1985, government subsidy for New Zealand agriculture is lacking. This lack of support provides opportunity for the farmers to strive to achieve success and leading the edge as compared to their counterpart from the rest of the world. Walker and Walker $(1987 b ; 1988)$ found that the stress levels vary among farmers who operate on different types of farms. For example, the financial status of farmers varies across sectors due to the impact of the world economy (such as, competitive global market and high interest rate (Olson \& Schellenberg, 1986; Reynolds \& Moore, 1990) More recently, the impact of global recession leads to reduce profit in dairy industry, whereas, the beef/sheep industry reported a higher profit (Hembry, 2009). Further, the simultaneous shifts in macro-economic policy have a direct impact on farmer income, such as carbon tax, compliance costs, increasing user pays charges, research and development policy and border security (Horticulture New Zealand, 2010).

\section{b. Adjusting to government regulations}

According to Booth and Lloyd (2000), occupational stress may be predicted to continue in the foreseeable future due to the continuing changes in farming practices which are influenced by government deregulations and the external environment. The primary industry sector in New Zealand has changed significantly in terms of deregulation of the agricultural sector and wider economic reforms since 1980 (Wilson, 1995). The changes in government policy have had a major impact on the process of restructuring in the rural sector to achieve sustainability. New Zealand farmers have been exposed to the full-force of the free market conditions, substantial changes in government policy (such as, environmental law) and the removal of subsidies (such as, fertiliser and pesticides). Subsequently, the New Zealand farmer has shown significant physical and emotional symptoms related to these changes in circumstances and the simultaneous shifts in macro-economic policy (Smith $\&$ Saunders, 1995). Further, the burden of compliance in the Employment Relations Act 2000 regime could provide the quest for better conditions in the rural labour market but this can be a real problem, especially when employing students to overcome labour shortage (Tipples, 2005; Tipples \& Martin, 2006).

\section{c. Labour shortage}

Since the demand for workers fluctuates in almost all agricultural sectors, a genuine skill shortage occurs when the farmers are having considerable difficulty in finding workers to work on the farm, coupled with insufficient job seekers (Baker, 2002). Skill shortages can incur a high cost to the economy because it can constrain the output of the agricultural production. The availability of labour is most stressful among the farm owners during the peak season because by employing the right people at the right time they would ensure that return is maximize (Tipples, 2001). Further, these sectors have trouble in recruitment and retention because they provide poor remuneration and employment practices, and make some less skilled jobs unattractive (Baker, 2002). On the contrary, the employers who possess positive attitudes 
toward their staff would experience low turnover and improved job satisfaction (Tipples, 2001).

\section{d. Effect of trade globalisation}

The advances in technology and government policies were introduced to support trade worldwide. Legislation and regulation by government has been also found to interfere in the daily farm work that increases farmers' workloads (Swisher, Elder, Lorenz, \& Conger, 1998). Like other self-employed managers, farmers can be isolated in their work, due to long working hours. Their social contact and business knowledge is crucial to remain solvent in the face of declining terms of trade in export, due to the supply constraints of world trade and worldwide competition (Brenmuhi, 2007; Burgess, 2007).

The increasing globalization of the New Zealand economy means that the farmers are more economically exposed to events taking place in other countries. Globalization has meant increased competition and opportunity for New Zealand farming industry. The successful farm businesses are the ones that can best adapt in response to competition and changes in the world economic situation. Those who react negative reactions to changes in the competitive environment will experience distress in the form of anxiety and depression, decreased in job satisfaction, and reduced job performance (Collins, 1998). The trade globalization that farmers will have to deal with will increase the need for diversification in farming, leading to a potential source of strain on the farmer's mental health. To be a good producer, the farmers have to be specialized and motivated to produce the most profitable products. A high level of capital is necessary to expand. For example, there has been huge investment in automation and robotics in the horticultural industry where it is essential for the growers to achieve sustainability. This could target affluent customers in less developed markets and thus contribute to future earnings for the industry (Horticulture New Zealand, 2008).

\section{e. Climatic conditions}

This trend magnifies some of the other stress sources, such as weather. Weather is an uncontrollable event. The timing of bad weather may have a major impact during the peak season on the success of the business (Deary, Willock, \& McGregor, 1997). For example, the droughtstricken Hawkes Bay and Waikato farmers are experiencing emotional states of distress (Anderson \& Gerbing, 1988; Pedersen, 2007). Consequently, in 2008, the farming community is reported to be in crippling drought conditions where there was a seriously short supply of stock feed for cows and sheep. The downturn in dairy production could cost half a billion dollars loss to the dairy farmers. According to Pederson (2007), "it is not an event which happened in their life times" (p. A2). Similarly, as for the horticultural industry, suitable temperatures for growth in fruit and vegetables are the most important requirements for success (Thorn, 2010).

\section{f. Size of the farm}

The New Zealand agricultural sector is more dominated by smaller and family farm businesses than in most other countries. As self employed workers, they are at greater risk than employees (Cryer \& Fleming, 1987). Although a large number of New Zealand small farms are sufficiently managed by family members, farm workers are normally not employed to overcome the labour shortage in the dairy, sheep, and cattle sectors. For example, in the period 1994-2002, the strong growth in the national dairy herd resulted in the average dairy farm increasing from 102 to 146 hectares. There were 14,000 farms engaged in dairy cattle farming in 2002 and they occupied 2.1 million hectares of land. Horticultural farm sizes increased by 95 percent from 1994, reaching an average farm size of 18.4 hectares in 2002. Land occupied by fruit, flower and vegetable growers was 231,580 hectares in 2002 (New Zealand Department of Statistics, 2005). Overall the size of the farm has been increased by 95 percent for horticultural farms, 43 percent for dairy and cattle farms. Since most farmers are owners in New Zealand who are usually sole proprietors, they often suffer from stress. The effects of stress on those working in the agricultural sector have been traditionally overlooked or minimized. The farmers who own relatively small farm will experience greater stress and they are at a greater risk of suicide than the large farm entrepreneurs (Hawton et al., 1999; Hawton et al., 1998). Little research has been done on the effect of stress on New Zealand small to medium farm owners. The experience of stress is especially problematic as most farmers who own farms, employ few staff, thus they are working harder. In essence, the primary responsibility for running the entire farm rests on the shoulders of the farm owners/managers. The farm owners should possess a unique way of working on the farm with a leadership style, which is not the same as what is usual for managers in large firms and organizations. Many farmers perceive their managerial role as a life-style, rather than as an entrepreneur, leading and controlling a firm (Olsson, 1988).

To conclude, the occupational stress features by farmers has revealed findings of negative consequences and the development of physical and mental disorders. The effects of stress on individuals are not only mental illness, but coronary heart disease, cancer, and a series of minor health complaints of a physical or psychological nature (Cooper, Liukkonen, \& Cartwright, 1996). Further, by comparing all the New Zealand occupational industries, the farmers consistently sustain higher rates of injuries and file more complaints of stress injuries for the past 10 years (Accident Compensation Corporation, 2006).

\section{Prior Research Examining Model of Occupational Stress}

Stressful work activity has been associated with specific occupations. Any type of occupation has been found to cause some negative effects on workers, but certain work activities are more likely to lead to be more stressful than other activities (Koslowksy, 1998). Early research on stressful occupations mainly concentrated on manufacturing, policing and nursing. Recently there have 
been attempts to expand the research on occupational stress to include other industries and incorporate other disciplines (Lo \& Lamm, 2004). The stressor measurement found in most of the literature concerns job stressors among employees in the organization. These studies focus on employed staff in a range of occupations, such as in the university, church, factory and school (Chen \& Spector, 1991), fire and police employees (Schaubroeck, Ganster, \& Fox, 1992), and academic staff (Kinman, 2001). These numerous studies on work-related stress provide a broader understanding of occupational stress and its consequences.

One of the main issues in occupational stress research is concern with the way individuals protective factors (such as, personality and coping styles) attempt to deal with stressors in order to avoid the aversive of strains (Beehr, Johnson, \& Nieva, 1995). There are two models of occupational stress put forth to describe the psychosocial effects of work environments: Karasek's on occupational stress model (1979).

\section{Occupational Stress Model.}

Robert Karasek's (1979) model of occupational stress is based upon the concept that mental strain is the result of the interaction of psychological demands and the personal control to meet demands of the job. Strain is highest when job demands are high and job control is low. Conversely, growth and development occur when job demands and job control are high. Further, an individual who has no personal control may not experience psychological strain but may lose interest in working activities during low job demands. The job demands are psychological stressors present in the work environment, such as the perceived need to work fast and hard. The demands in the Karasek's model produce a state of stressful arousal, whereas personal control is the individual's capacity to make decisions and ability to perform variety of skills. The framework of job demands and control will predict the level of psychological strain and risk of physical illness (Karasek \& Theorell, 1990; Kristensen, 1996). Individual believes they have control in determine their affective responses, such as job satisfaction and strain. In effect, strain is the result from an incompatible fit between demands of a job and personal abilities of individual (Lazarus \& Folkman, 1984). Strain is an unpleasant outcome that may result in negative consequences that include poor health, mental health problems, bad behavioural symptoms and lower productivity (French, Caplan, \& Van Harrison, 1982; Koslowksy, 1998). According to this theory, individuals who work in a highly demanding environment with low personal control over their job-related activities would experience the negative effects of psychological and physiological outcome. However, too much control can be damaging for the individual, but just as too little control is harmful. Similarly, increased control in one's job may imply additional responsibility for outcomes, and for some individual the more responsibility may be a burden rather than a challenge (Spector, 1998). According to Xie, Schaubroeck, and Lam, (2008), the typical job demands or stressors are constituent of the complexity and amount of workloads perceived by workers, whose workloads are supervised by their superiors. Hence, there was considerable support for the Karasek's model, where control buffers the negative effect of demands which may lead to strain (De Lange, Taris, Kompier, Houtman, \& Bongers, 2003). Some workers may actually experience stress and strain according to the occupational stress model.

The Karasek's occupational stress model eventually expanded to include social support (Theorell, 2003). According to this theory, depending on the level of social support, individuals whose jobs are high in demands and low in control are likely to report varying level of health symptoms. However, it is still unclear whether the measure of social support is individual differences in perceptions of support level factor or actual contextual differences in support factor, or both of these factors. This may explain why the level of analysis ambiguity results inconsistent in numerous empirical research findings (Bliese \& Britt, 2001). In sum, researchers have explored further the variations of the Karasek's model by including either additive or interactive influences of job characteristic (such as, social support) and dispositional characteristics (such as, personality traits) (Parkes, Mendham, \& Von Rabenau, 1994; Tetrick \& LaRocco, 1987).

Overall, the Karasek's occupational stress model has been included in this study because this theoretical conceptualization of occupation stress is relevant to understand the complex nature of job stress in the farming industry and its implication.

\section{The Present Study}

New Zealand has the highest number of workers employed in the primary sector amongst the developed countries (International Labour Organization, 2003). According to the International Labour Organization report (2003), the agricultural sector in New Zealand constitutes less than $10 \%$ of the New Zealand work force.

There is a large body of literature related to stress in general, but there is a limited body of research how it relates to occupational stress in farming, particularly in Australasia. This study will make major effort to present literature that is pertinent to model of occupational stress that reflect its relevance. This may be broken down into two research questions drawn from the farming stress literature:

First, what is level of occupational stress among the New Zealand farmers?

Next, what is the occupational stress level in the New Zealand farming industry compare with European countries, such UK.

\section{Method \\ Sample and procedure}


Participants in this study included farmers, orchardists, sharemilkers, and salaried farmers. They are recruited from the farming organizations between July 2007 and September 2007. The average age of participants was 48 years, and approximately three-quarter of them were male farmers from diverse farming sectors. The racial composition of the sample was as follows: $88 \%$ were New Zealand Pakeha, $1.5 \%$ were Maori, $4.4 \%$ were "New Zealanders", 1.3\% were European, 0.2\% were African, and $0.1 \%$ were Asian.

This study used the internet and magazines that were readily available to the members. They were assigned to every member in a target population with a known probability of being selected, which avoided coverage error. The sample size provided a basis for the estimation of sampling error (Hair, Black, Babin, Anderson, \& Tatham, 2006). The respondents were informed that the questionnaire would take twenty minutes to complete.

This result of this study is compared with the empirical data from the existing published journal. The comparison with participants from different countries will indicate the extent of occupational stress (Booth \& Lloyd, 2000).

\section{Measures}

Two established instruments were utilized in this study comprising of forty-six scale items. Edinburgh Farming Stress Inventory ((Deary, et al., 1997) and General Health Questionnaire-12 (Kalliath, O’Driscoll, \& Brough, 2004) are used to gather information. The existing scales were used to measure the constructs in this study. Each component of the survey instrument contained a Likerttype scale to rate the respondent's answers.

\section{Empirical Evidence}

A total of 1,041 individual questionnaires were received from surveys. However, there was no information gathered on the possible number of members in each sector of the agriculture industry, which has resulted in an inability to calculate a response rate for each sector.

The result of this study reveal that Edinburgh Farming Stress Inventory (Stressor) variable was positively associated $(\mathrm{r}=0.46, \mathrm{p}<.01)$ with General Health Questionnaire-12. However, this result contradicts to the proposed acceptable correlation of about .26 and .40 in a stressor-strain study as suggested by Zapf, Dormann, \& Frese (1996) and Koslowsky (1998) respectively. Taking into this account, it is reasonable to suggest that the correlation of stressor-strain in the farming populations could achieve higher value.

A total of six domains consisting of thirty-four items to assess the farm-related stress have been identified in the inventory: 1) government bureaucracy; 2) financial debts; 3) unpredictable factors in farming (such as, weather and machinery breakdown at busy times; 4) time pressures; 5) personal farm hazards; and 6) geographical isolation. The between factor correlation of the farm stressors are reported in Table 1 below:

Table 1: Between-factor Correlations of the farm inventory

\begin{tabular}{|c|c|c|c|c|c|c|}
\hline & $\begin{array}{l}\text { Finance } \\
\text { (F1) }\end{array}$ & $\begin{array}{l}\text { Farm } \\
\text { Hazards } \\
\text { (F 2) }\end{array}$ & $\begin{array}{l}\text { Isolations } \\
\text { (F 3) }\end{array}$ & $\begin{array}{l}\text { Time } \\
\text { Pressure } \\
\text { (F 4) }\end{array}$ & $\begin{array}{l}\text { Govt. } \\
\text { (F 5) }\end{array}$ & $\begin{array}{l}\text { Unpredictable } \\
\text { Factor's } \\
\text { (F 6) }\end{array}$ \\
\hline F 1 & 1 & 0.45 & 0.37 & 0.56 & 0.41 & 0.41 \\
\hline $\mathrm{F} 2$ & & 1 & 0.40 & 0.60 & 0.40 & 0.45 \\
\hline F 3 & & & 1 & 0.53 & 0.25 & 0.30 \\
\hline $\mathrm{F} 4$ & & & & 1 & 0.41 & 0.48 \\
\hline F 5 & & & & & 1 & 0.34 \\
\hline F 6 & & & & & & 1 \\
\hline
\end{tabular}

The farm managers in the present study rated complying with government policies and regulations, unpredictable factors, personal farm hazards, time pressure, and finance issues, and geographical isolation among their sources of farm stress. Interestingly, the farmers report comparatively high severity of stress similar to UK farmers (such as Deary et al.,1997) with mean of 3.3 (SD $=1.2$ ) for F5 ("Adjusting to new government regulations and policies"; "Filling government forms") mean of 3.3 $(\mathrm{SD}=1.4)$. Along a similar line, the other UK study reported most of the stressful items were related to government bureaucracy (Booth \& Lloyd, 1999; Pollock et al., 2002; Simkin, Hawton, Fagg, \& Malmberg, 1998; Walker \& Walker, 1988). Furthermore, the results of the study supported that the farm managers identified similar farm stressors as reported in previous studies (such as, Alpass et al., 2004; Deary et al., 1997).

The results of this study explain that the farmers actually demonstrate low strain from the impact of stressors. These are partly the function of low government regulatory pressures and free outbreak of diseases or incidents of prolong bad weather in the New Zealand farms. Moreover, the New Zealand farming organizations provide the social supportive structure for the farmers. In this context, Linn and Husaini (1987) found that social support group was a protective factor in the farming community. Moreover, in relation to the Karasek's job strain model (Karasek \& Theorell, 1990), the present study found initial support those farmers, member of farming organization perceived organization support as a favourable work outcome. The farm managers with a sense of job control with support from the organizations are likely to experience low occupational stress because they feel that they can influence various outcomes in their job. In addition, this finding suggests that farmers are capable of handling multi-tasks as well as confronting with external demands in the farm.

In contrast, the UK and Dutch farmers will have had to face the consequences of the diseases outbreak (such as, foot and mouth disease) and its aftermath due to financial uncertainty (Lobley et al., 2004; Olff et al, 2005). The other factor for variation in the strain level among the New Zealand and European, particularly, UK farmers are reflected in the government policies and regulations. There is a far greater government regulatory pressure 
under the reformed EU Common Agricultural Policy (CAP) experience by European and UK farmers. Taken together, by international comparison, the New Zealand farmers are not experiencing psychological strain because of low impact of stressors which has implications for policy makers. Further, the results of this research have practical relevance to farming organizations and professional practice.

\section{Implications of the study}

Since stress is recognized as a key concern in farming literature, and there is an overwhelming concern due to its impact on farmers' mental health. The multifaceted effects of stress include various environmental factors are likely to interact in different ways that affect the farmers' psychological well-being. Thus, the interaction of farm stressors will determine one's perceived strain level.

Next, the outcome of the study will inform practices to identify areas where the industries can make improvements and identify appropriate training help to reduce strain levels. For example, the New Zealand coaching and rural mentor training will provide the opportunity for networking and personal development among the farmers in the rural sector (Allen, 2009).

\section{Conclusion}

The farmers reported a high impact of stressors complying with government policies \&regulations, but a comparatively low impact of stressors in relation to geographical isolation. The occupational stress in New Zealand farming industry is found to be consistent with those reported elsewhere, particularly in the Australian and British farming populations. Farmers who experience stressful events while doing farm work tend to report psychological strain. The results support the notion that the low impacts of stressors generate low levels of strain among New Zealand farming managers. This can have spillover effects into other aspects of farming life.

\section{Notes}

The author would like to thanks Asso. Prof. Felicity Lamm, Auckland University of Technology who presented this paper at the LEW14 conference.

\section{References}

Accident Compensation Corporation (2006), ACC Injury Statistics 2006 (first edition), Wellington: Government printer.

Allen, J. (2009). Rural mentor programme. Paper presented at the New Zealand Institute of Primary Industry Management 2009 Conference.

From

http://www.nzipim.co.nz/2009_National_Confer ence_James_Allen_slides.

Alpass, F., Flett, R., Humphries, S., Massey, C., Morriss, T., \& Long, N. (2004). Stress in dairy farming and the adoption of new technology. International Journal of Stress Management, 11(3), 270-281.

Anderson, J. C., \& Gerbing, D. W. (1988). Structural equation modeling in practice: A review and recommended two-step approach. Psychological Bulletin, 103(3), 411-423.

Arnold, J., Cooper, C. L., \& Robertson, I. T. (1998). Work psychology understanding human behavior in the workplace (3rd ed.). Harlow: Pearson Education Ltd.

Baker, J. (2002). The Skills Employers Needed. In $S$. Maharey WorkINSIGHT (Vol. 1). Wellington: Department of Labour.

Beehr, T. A., Johnson, L. B., \& Nieva, R. (1995). Occupational stress: Coping of police and their spouses. Journal of Organizational Behavior, 16(1), 3-25.

Bliese, P. D., \& Britt, T. W. (2001). Social support, group consensus and stressor-strain relationships: Social context matters. Journal of Organizational Behavior, 22(4), 425436.

Booth, N. J., \& Lloyd, K. (2000). Stress in farming. International Journal of Social Psychiatry, 46(1), 67-73.

Brenmuhi, F. (2007). Economics woes worry dairy farmers. Retrieved July 17, 2007, from http://www.ruralnews.co.nz.

Burrow, S. (2002). Occupational stress: The union perspective. Paper presented at the Academy of the Social Sciences Australia Workshop on Occupational Stress, Adelaide, South Australia, Australia.

Burton, W. B., Chen, C., Conti, D. J., Schultz, A. B., Pransky, G., \& Edington, D. W. (2005). The association of health risks with on-the-job productivity Journal of Occupational \& Environmental Medicine, 47(8), 769-777.

Byrne, B. (2001). In Structural equation modeling with Amos: Basics concepts, applications and programming. Mahwah, New Jersey: Lawrence Erlbaum Associates.

Chen, Y., \& Spector, P. E. (1991). Negativity affectivity as the underlying cause of correlations between stressors and strains. Journal of Applied Psychology, 76(3), 398-407.

Coggan, C. A., Fanslow, J. L., \& Norton, R. N. (1995). Intentional injury in New Zealand. Analysis and monitoring report 4. Wellington: Public Health Commission.

Collins, D. (1998). Organisational change: Sociological perspectives. London: Routledge.

Cooper, C. L., \& Bramwell, R. S. (1992). A omparative analysis of occupational stress in managerial and shopfloor workers in the brewing industry: Mental health, job satisfaction, and sickness. Work \& Stress, 6(2), 127-138.

Cooper, C. L., Liukkonen, P., \& Cartwright, S. (1996). Stress prevention in the Workplace: Assessing the costs and benefits for organizations. Dublin: Paper presented at the European foundation for the improvement of living and working conditions. 
Cryer, P. C., \& Fleming, C. (1987). A review of workrelated fatal injuries in New Zealand 1975-84, numbers, rates and trends. New Zealand Medical Journal, 100(816), 1-6.

Deary, I. J., Willock, J., \& McGregor, M. (1997). Stress in Farming. Stress Medicine, 13(2), 131136.

Department of Labour (2004). Industry profileagriculture and horticulture. Wellington: Department of Labour.

Department of Labour (2007). Annual Report 20062007, Retrieved July 16, 2008, from http://www.dol.govt.nz.

Eberhardt, B. J., \& Pooyan, A. (1990). Development of the Farm Stress Survey: Factorial structure, reliability and validity. Education and Psychological Measurement, 50(2), 393-402.

Firth, H. M. (2001). Health of farmers in Southland: An overview. New Zealand Medical Journal, 114, 426-428.

French, J. R. P. Jr., Caplan, R. D., \& Van Harrison, R. (1982). The mechanisms of job stress and strain. Chichester, England: Wiley.

Grant, S., \& Langan-Fox, J. (2007). Personality and the occupational stressor-strain relationship: The role of the big five. Journal of Occupational Health Psychology, 12(1), 20-33.

Hawton, K., Fagg, J., Simkin, S., Harriss, L., Malmberg, A., \& Smith, D. (1999). The geographical distribution of suicides in farmers in England and Wales. Social Psychiatry and Psychiatric Epidemiology, 34(3), 122-127.

Hawton, K., Fagg, J., Simkin, S., Harriss, L., Malmberg, A., \& Smith, D. (1998). Methods used for suicide by farmers in England and Wale.. The contribution of availability and its relevance to prevention. The British Journal of Psychiatry, 173, 320-324.

Hembry, O. (2009). Farmers on long road to recovery. The NZ Herald, p. 3, Retrieved Mar 05, 2009 from http://www.nzherald.co.nz/nz/news/article.cfm?c $\mathrm{id}=1 \&$ objectid $=10560019$

Hoel, H., Sparks, K., \& Cooper, C. L. (2001). The cost of violence/stress at work and the benefits of a violence/stress-free working environment. Geneva: International Labour organization.

Hope, A., Kelleher, L. H., \& Hennessy, T. (1999). Health and safety practices among farmers and other workers: a needs assessment. Journal of Occupational Medicine, 49(4), 231-235.

Horticulture New Zealand. (2008). Horticulture New Zealand Homepage: New Zealand fresh vegetable industry. Retrieved April 4, 2008, from http://www.freshvegetables.co.nz/research.html

Horticulture New Zealand. (2010). Horticulture New Zealand Homepage. Retrieved April 16, 2010, from http://www.hortnz.co.nz

Karasek, R. (1979). Job demands, job decision latitude, and mental strain: Implications for job redesign. Administrative Science Quarterly, 24(2), 285308.
Karasek, R., \& Theorell, T. (1990). Healthy work: Stress, productivity, and the reconstruction of working life. New York: Basics Books.

Kinman, G. (2001). Pressure points: A review of research on stressors and strains in UK academics. Educational Psychology, 21(4), 473492.

Koslowksy, M. (1998). Modeling the stress-strain relationship in work settings. London: Routledge progress in psychology.

Kalliath, T., O"Driscoll, M., \& Brough, P. (2004). A confirmatory factor analysis of the General Health Questionnaire-12. Stress and Health, 20 (1), 11-20.

Koslowksy, M. (1998). Modeling the stress-strain relationship in work settings. London: Routledge progress in psychology.

Lazarus, R., \& Folkman, S. (1984). Stress, appraisal and coping. New York: Springer.

Linn, J. G., \& Husaini, B. A. (1987). Determinants of psychological depression and coping behaviours of Tennessee farm residents. Journal of Community Psychology, 15(4), 503-512.

Lo, K., \& Lamm, F. (2004). Occupational Stress in the Hospitality Industry: An employment relations perspective. New Zealand Journal of Employment Relations, 30(1), 23-48.

Lobley, M., Johnson, G., Reed, M., with Winter, M., \& Little, J. (2004). Rural stress review final report. UK: Centre for Rural Research, University of Exeter

Morgaine, K., Langley, J. D., \& McGee, R. O. (2006). The FarmSafe Programme in New Zealand: Process evaluation of year one. Safety Science, 44(4), 359-371.

National Institute for Occupational Safety and Health. (2002). Occupational exposure to hot environments, revised criteria Washington, DC: Department of Health and Human Sciences.

New Zealand Department of Statistics. (2005). New Zealand Agriculture Statistics. Wellington: Government printer.

Olff, M., Koeter, M. W. J., Haaften, E. H. V., Kersten, P. H., \& Gersons, B. P. R. (2005). Impact of a foot and mouth disease crisis on post-traumatic stress symptoms in farmers. British Journal of Psychiatry, 186(2), 165-166.

Olson, K. R., \& Schellenberg, R. P. (1986). Farm Stressors. American Journal of Community Psychology, 14(5), 555-569.

Olsson, R. (1988). Management for success in modern agriculture. European Research, 15, 239-259.

Parkes, K. R., Mendham, C. A., \& Von Rabenau, C. (1994). Social support and the demanddiscretion model of job stress: Tests of additive and interactive effects in two samples. Journal of Vocational Behavior, 44(1), 91-113.

Pedersen, C. (2007). Federated Farmers of New Zealand. Federated Farmers Update. Federated Farmers of New Zealand, 2.

Pollock, L., Deaville, J., Gilman, A., \& Willock, J. (2002). A Preliminary Study into Stress in 
Welsh Farmers. Journal of Mental Health, 11(2), 213-221.

Reynolds, R., \& Moore, W. (1990). Farm prices and costs. Wellington: Government Publications.

Sayetta, R. B., \& Johnson, D. P. (1980). Basic data on depressive symptomatology, United States, 1974-75 DHEW Publication No. PHS 80-1666. Washington DC: GPO.

Schaubroeck, J., Ganster, D. C., \& Fox, M. L. (1992). Dispositional affect and work-related stress. Journal of Applied Psychology, 77(3), 322-335.

Schellenberg, R., Olson, K., \& Fuller, D. (1985). Burnout and stress in farmers. Paper presented at the 1985 Summer Conference on the National Association for Rural Mental Health.

Shadbolt, N., \& Martin, S. (2005). Farm management in New Zealand. Melbourne: Oxford University Press.

Spector, P. E. (1998). A control theory of the job stress process In C. Cooper (Ed.), Theories of organizational stress (pp. 153-169). New York: Oxford University Press.

Simkin, S., Hawton, K., Fagg, J., \& Malmberg, A. (1998). Stress in farmers: A survey of farmers in England and Wales. Occupational and Environmental Medicine, 55(11), 729-734.

Smith, W., \& Saunders, L. (1995). Agricultural policy reforms and sustainable land management: A New Zealand case study. Australian Geographer, 26(2), 112-118.

Swisher, R., Elder, G., Lorenz, F., \& Conger, R. (1998). The long arm of the farm: How an occupation structures exposure and vulnerability to stressors across role domains. Journal of Health and Social Behavior, 39(1), 72-89.

Tetrick, L. E., \& LaRocco, J. M. (1987). Understanding prediction, and control as moderators of the relationships between stress, satisfaction, and psychological well-being. Journal of Applied Psychology, 72(4), 538-543.

Thorn, A. (2010). Horticulture New Zealand Homepage: Product groups. Retrieved April 3, 2010, from http://www.hortnz.co.nz/Overview/Productgroups/Introduction.htm

Tipples, R. (2001). Getting and holding seasonal staff. Winepress, 102, 18-24.

Tipples, R. (2005). Self-management and managing e mployee. In N. Shadbolt, \& S. Martin (Eds.), Farm management in New Zealand (pp. 182200). Melbourne: Oxford University Press.

Tipples, R. S., \& Martin, S. M. (2006) Getting Produce from the New Zealand paddock to the European Plate - reducing supply chain vulnerability through the management of employment relations critical control points, New Zealand Journal of Employment Relations, 31(1), 60-75.

Walker, J., L., \& Walker, L. J. S. (1987). Individual differences in occupational stress and stress symptoms among farmers. Paper presented at the Applications of individual differences in stress and health psychology, Winnipeg, Manitoba.

Walker, J., L., \& Walker, L. J. S. (1987b). Stressors and symptoms predictive of distress in farmers. Family Relations, 36(4), 374-378.
Walker, J., L., \& Walker, L. J. S. (1988). Self-reported stress symptoms in farmers. Journal of Clinical Psychology, 44, 10-16.

Wilson, O. J. (1995). Rural restructuring and agriculturerural economy linkages: A New Zealand study. Journal of Rural Studies, 11(4), 417-431.

Xie, J. L., Schaubroeck, J., \& Lam, S. K. (2008). Theories of job stress and the role of traditional values: A longitudinal study in China. Journal of Applied Psychology, 94(4), 831-848.

Zapf, D., Dormann, C., \& Frese, M. (1996). Longitudinal studies in organizational stress research: Review of the literature with reference to methodological issues. Journal of Occupational Health Psychology, 1(2), 145-169. 